\title{
UBUNGAN ANTARA KEPRIBADIAN TIPE D DAN FAKTOR FISIOLOGI DENGAN VITAL EXHAUSTION PADA PASIEN INFARK MIOKARD
}

\author{
Dian Novita*)
}

*) Program Studi Ilmu Keperawatan Universitas Malahayati Bandarlampung

\begin{abstract}
Abstrak
exhaustion (VE) merupakan prediktor utama terjadinya infark miokard (IM), diduga kepribadian D mempunyai hubungan independen dengan VE. Hubungan kepribadian tipe-D, faktor fisiologi: sterol total, indeks masa tubuh (IMT), high density lipoprotein (HDL), low density lipoprotein (LDL), tekanan darah diastolik (TDD), serta faktor gaya hidup dengan VE, telah diungkapkan oleh beberapa namun belum jelas. Penelitian ini bertujuan untuk mengindentifikasi hubungan antara kepribadian D dan faktor fisiologi berbungan dengan terjadinya VE pada pasien IM penelitian ini menggunakan da cross sectional designs. Dengan jumlah sampel sebanyak 68 yang dipilih menggunakan teknik ecutive sampling pada subjek yang datang dirawat di ICCU RSUPN Cipto Mangunkusumo dan ung Perawatan lantai 3,4, dan 5 RSJPD Harapan Kita Jakarta, mulai tanggal 1 Mei sampai dengan 15 2009. VE diukur dengan 21 pertanyan dari Maastric Questionnaire, kepribadian tipe-D terdiri dari ciri afekif negatif (AN) 7 dan hambatan sosial (HS) 7 pertanyaan, faktor fisiologi: IMT, kolesterol , HDL, LDL, dan TDD data sekunder yang didapat pada catatan medis pasien. Karakteristik subjek upakan perancu. Hasil penelitian membuktikan kepribadian tipe D, kolesterol total dan TDD ubungan signifikan dengan VE dan faktor yang paling berhubungan dengan VE adalah kepribadian D. $\mathrm{p}=0,01 \alpha: 0,05$, OR 6,83 (CI:1,58-29,48). Simpulan penelitian ini yaitu pasien IM yang epribadian tipe-D mempunyai peluang 6,8 kali mengalami VE dibanding pasien IM bukan tipe-D ah dikontrol oleh kolesterol total, TDD dan peminum minuman keras, dan pasien dengan kolesterol berisiko berpeluang 5,9 kali mengalami VE dibanding dengan kolesterol total tidak berisiko setelah ntrol oleh tipe-D, TDD, dan peminum minuman keras, serta pasien dengan TDD berisiko berpeluang cali mengalami VE setelah dikontrol TDD tidak berisiko, kolesterol total dan tipe-D. Rekomendasi litian adalah memasukkan kepribadian tipe-D dan VE, dalam format pengkajian asuhan keperawatan tiap seting pelayanan pasien jantung.
\end{abstract}

kunci: faktor fisiologi: kolesterol total, HDL, LDL, tekanan darah diastolik, kepribadian tipe-D, $\mathrm{k}$ miokard, vital exhaustion.

\section{AHULUAN}

xhaustion/ VE menurut beberapa peneliti kan sebagai faktor pencetus atau itor IM dan kematian jantung mendadak Appels, Mendes, Swart, \& Bar 1994). VE arkan dengan beberapa gejala fisik umum dialami dengan tiga ciri utama, yaitu an berlebihan dan kurangnya energi, katan iritabilitas, dan perasaan lisasi (Appels, et al., 1995). Studi ctif pada sekelompok pasien di klinik ukkan bahwa pengkajian VE tribusi untuk mengidentifikasi pasien o peningkatan IM (Schuitemaker, Dinant, r Pol, \& Appels, 2004). Hal ini diperkuat dengan studi epidemiologi yang menyatakan bahwa mayoritas pasien merasakan perasaan VE sebelum terjadinya IM ( $\mathrm{p}$ value $<0,03$ ) (Appels \& Mulder, 1988 dalam Raikkonen, 1997). VE selain sebagai prediktor IM juga merupakan gejala setelah post IM. Diperkirakan lebih kurang $30 \%$ sampai $60 \%$ dari pasien PJK mengalami gejala ini (Stowers \& Short, 1970 dalam Kilbourn, Saab, \& Schneiderman, 2000). Vital exhaustion juga berhubungan dengan peningkatan perbandingan kadar hormon insulin dan CPeptide dengan kadar glukosa dalam darah lakilaki dewasa. 
Perbandingan kadar insulin dan peningkatan kadar glukosa darah sangat mempengaruhi kejadian obesitas yang secara tidak langsung sebagai faktor risiko penyebab VE (Raikkonen, Keltikangas-Jarvinen \& Hautanen, 1994). Perubahan metabolisme lipid kemungkinan dapat menjadi mediasi antara VE dan PJK dan IM. Kolesterol high-density lipoprotein cholesteroll HDL-C dan apolipoprotein Al mempunyai hubungan dengan VE (Koertge, Ahnve, Schenck-Gustafsson, Orth-Gomer, \& Wamala 2003). Obesitas, hyperglikemia, dan dislipidemia pada laki-laki sehat usia pertengahan berpotensi berhubungan dengan VE (Raikkonen, et al. 1996 dalam Koertge, 2003).

Penelitian oleh Jeanmonod, Kanel, Maly, dan Fiecher (2004), yang mengidentifikasi pengaruh VE berat pada tingkat plasma $C$-reactive protein (CRP) dan apakah exhaustion berpengaruh pada regulasi tingkat CRP pada pekerja pembuatan pesawat terbang di Jerman selatan $(\mathrm{N}=275)$. Mereka membuktikan subjek dengan peningkatan exhausted bermakna pada peningkatan tingginya low density lipoprotein/ LDL (p:0,02). Penelitian tersebut terkait dengan kontribusi pengkodean gen untuk inflamsi protein plasma yang berhubungan dengan pembentukan risiko pada PJK.

Penelitian oleh Bryant, Stevens, Truesdale, Mosley dan Chambless (2008) yang bertujuan untuk mengetahui hubungan antara indeks masa tubuh/ IMT dan VE yang diamati selama 3.6 bulan pada 13.727 orang dewasa (ras kulit putih dan Amerika-Afrika) menunjukan bahwa ada hubungan yang signifikan peningkatan IMT antara kedua ras kulit putih dan Afrika-Amerika baik laki-laki maupun perempuan dengan VE dibanding yang tidak mengalami VE. Peningkatan berat badan (semua ras) dan kelebihan berat badan (ras kulit putih) mempunyai risiko tinggi terjadinya VE. Faktor fisiologi seperti tingginya tekanan darah/ hipertensi dapat meningkatkatkan beban jantung, meningkatkan kontraksi jantung dan dalam waktu lama terjadi peregangan serat otot jantung dan terjadi pembesaran ventrikel yang berlanjut pada penurunan kontraksi, penurunan curah jantung dan saturasi oksigen. Hal ini menyebabkan hipoksia yang menghasilkan gejala pusing, kelemahan, dan kelelahan (El-Mokadem, 2003).
Peningkatan tekanan darah diastolik $>10 \mathrm{~mm}$ dalam jangka panjang akan meningkatkan ris PJK sebesar $37 \%$. Saat tekanan diastolik n 95-100 $\mathrm{mmHg}$, risiko kejadian serebral jantung dimasa datang menjadi bermakna $\left(\mathrm{G}_{\mathrm{r}}\right.$ Dawkins, Simpson, \& Morgan, 2002). Exhaust adalah suatu masalah yang dirasakan bermal oleh pasien IM. hubungan khusus ant exhaustion dan faktor-faktor lain sep fisiologis, psikososial, dan faktor situasio adalah tidak jelas (Piper, 1991 dalam Mokadem, 2003). Meskipun, peran perilaku psikososial oleh beberapa penelitian te dibuktikan sebagai faktor risiko dalam etiol dan patogenesis PJK dan IM (Denollet, 19 Sher, 2005). Pola perilaku yang paling dike adalah kepribadian tipe-A yang sangat beris mengalami PJK cirinya termasuk ambisi agresif, kompetatif, tidak sabar, kasar, sir bermusuhan, dan gampang marah (Sher, 200 Hasil penelitian Western Collaborative Gro Study, diikuti selama 22 tahun menemul perilaku tipe-A adalah tidak mempredi perkembangan penyakit kardiovaskuler (Ragla \& Brand, 1988 dalam Williams, O’Carroll, O'Connor, 2007). Sementara lebih dari s dekade uraian dari perilaku tipe A belum je dalam mempertahankan prediksi kualitas terk dengan kejadian PJK (Gallacher, Sweetna Yarnell, \& Elwood, 2003) karena ditemukan p yang tidak konsisten pada perilaku tipe (Williams, O'Carroll, \& O'Connor, 200 Penelitian pada kepeminatan kepribadian seba: faktor risiko penyakit jantung dalam jang waktu lama, yaitu tipe kepribadian tertek (distressed) atau kepribadian tipe-D (Sher, 200 Kepribadian tipe-D digambarkan sebagai indivi yang mengalami peningkatan emosi negatif $d$ tidak mengekspresikan emosi dalam berinteral sosial (Pedersen, Lemon, van Vooren, L Daemen, \& Erdman, Smits, Serruys, \& Domburg, 2004). Kepribadian Tipe-D berisi tidak adekuat terhadap pengobatan, secs independen diprediksi mempunyai hasil kli yang kurang baik pada penyakit jantung iskem dan kekuatan prognosis kepribadian tipe-D sa dengan disfungsi ventrikel kiri (Pedersen, et 2004). Beberapa ahli menganjurkan perlur pengembangan penelitian kedepan terkait deng mekanisme kepribadian tipe-D dan bagaima 
mempunyai keuntungan dari intervensi sosial dalam mencegah risiko terjadinya gan jantung, kekambuhan dan kematian. Di esia IM akut masih merupakan pembunuh . Menurut data dari Ditjen Yanmedik pada 2006 dari beberapa jenis penyakit jantung atality rate IM akut adalah $13,31 \%$, setelah uan hantaran dan aritmia sebanyak $13,95 \%$ enderung terjadi peningkatan (Depkes RI., - Populasi pasien IM tahun 2008 yang at di ICCU RSUPN Cipto Mangunkusumo 135 pasien atau $26,21 \%$ dari 515 total jantung (terdiri beberapa jenis penyakit

\section{ODE PENELITIAN}

tian menggunakan metoda deskriptif $\mathrm{k}$ dengan rancangan cross sectional. pada IM di RSUPN Cipto Mangunkusumo dan Harapan Kita Jakarta mulai tanggal 1 Mei i dengan 15 Juni 2009. Penelitian ini diikuti sponden pasien IM yang dijaring secara cutive sampling berdasar kritera inklusi: sponden antara 37-65 tahun, subjek dirawat al selama 24 jam, bebas dari nyeri, tidak angguan aritmia dan hemodinamik stabil, membaca dan menulis, dan bersedia di responden dengan menandatangani d consent. Penelitian ini menggunakan ner karakteristik responden meliputi: umur, kelamin, status perkawinan, riwayat ga, perokok tidak berisiko (tidak merokok, ti merokok $<1$ tahun, perokok $1-10$ batang ari) dan berisiko (perokok $>10$ batang i), peminum minuman keras tidak berisiko konsumsi minuman keras $\leq 1$ gelas per enis minuman bir, dan $\leq 1$ tahun) dan 0 (mengkonsumsi minuman keras $>1$ gelas ri, jenis minuman arak/wiski, dan $>1$ kebiasaan olahraga tidak berisiko hraga jalan sehat/ jogging dan atau senam i perminggu; >20 menit setiap beraktifitas)

\section{PENELITIAN}

iolah dan dianalisa menggunakan analisa at, bivariat dam analisis multivariate logistik ganda. Hasil analisis univariat it karakteristik responden menunjukkan pasien IM berumur 53,81 tahun, dengan jantung) dengan angka kematian 28,57\%. Sementara masih sedikit penelitian di Indonesia tentang faktor-faktor risiko terjadinya IM dan belum jelasnya hubungan antara perubahan gaya hidup dan psikososial yang dapat meningkatkan risiko pada PJK atau IM. Penelitian ini bertujuan untuk mengidentifikasi hubungan antara kepribadian tipe-D dan faktor fisiologis dengan VE pada pasien IM. Diharapkan penelitian ini memberikan manfaat bagi pasien, pemberi pelayanan kesehatan/ perawat, pengembangan pendidikan keperawatan, dan penelitian.

dan berisiko (tidak/ jarang berolahraga 1-2 kali per minggu, $\leq 20$ menit beraktifitas olahraga). Kuesioner vital exhaustion yang telah diukur secara lengkap dengan tes psikometrik, menunjukkan reliabilitas koefisien yang baik ( $\alpha=0,912$; Beges, Falger, Perez, \& Appels, 2000). Reliabilitas skala diukur dengan Cronbach's $\alpha=0.89$ (Appeles, et al., 1987, dalam Pedersen, 2007). Kuesioner Kepribadian Tipe-D terdiri dari skala afek negatif/ AN dan hambatan sosial/ HS diukur pada responden pasien dengan MI. Test dan retest yang dilakukan oleh Denollet (2005), menunjukkan reliabilitas koefisien yang baik adalah 0,82 dan 0,72 untuk AN dan HS secara berkelanjutan. Mengindikasikan kepribadian tipeD adalah stabil sepanjang waktu, dengan tingginya validitas internal dengan Cronbach's 0,88 dan 0,86 (Denollet, 2005). Data fisologis diambil pada catatan medik pasien saat pertama kali masuk rumah sakit. Meliputi kolesterol total, HDL, LDL, (satu minggu pertama saat dirawat), data IMT berdasar pada tinggi badan/ TB dan berat badan/ BB responden. Rerata tekanan darah distolik yang diambil pada catatan medik dari tiga kali pengukuran masing-masing satu kali dalam satu shift.

jenis kelamin terbanyak adalah laki-laki, sebagian besar ada pendamping, dan sebagian besar tidak mempunyai riwayat keluarga. Sebagian besar responden tidak perokok /tidak berisiko, dan lebih banyak responden kurang berolahraga. Lebih dari 
$1 / 3$ responden yang berkepribadian tipe-D. Karakteristik responden menurut faktor fisiologi: indeks masa tubuh/ IMT responden lebih banyak tidak berisiko dan kolesterol total lebih banyak yang berisiko. Sebagain besar responden dengan HDL, LDL tidak berisiko, dan sebagian besar responden berisiko dengan tekanan darah diastolik. Sebagian besar responden pasien IM mengalami VE.

Hasil analisis bivariat untuk karakteristik dengan VE terlihat adanya hubungan bermakna antara kebiasaan peminum minuman keras dengan VE pada pasien IM ( $p$ value 0,049 ) dan untuk umur, jenis kelamin, riwayat keluarga, status keluarga, kebiasaan olahraga, serta perokok tidak ada hubungan secara signifikan dengan VE. Terlihat adanya hubungan yang bermakna antara kepribadian tipe-D dengan VE pada pasien IM ( $p$ value 0,010 ). Hasil lebih lanjut pada uji regresi logistik adalah $\mathrm{OR}=6,8(95 \%$ CI: $1,58-29,48)$. Artinya pasien IM yang berkepribadian tipe-D mempunyai peluang 6,8 kali mengalami VE dibandingkan pasien IM yang bukan berkepribadian tipe-D setelah dikontrol variabel

\section{PEMBAHASAN}

Rerata umur responden IM yang menjadi subjek pada penelitian ini adalah 53,81 tahun dengan rentang usia 37-65 tahun, artinya rerata pasien IM menunjukan pada usia dewasa lanjut (50-64 tahun). Hal ini mendukung penelitian sari Ivanusa dan Ivanusa (2004) yang dilakukan di Bjelovar General Hospital, Croatia yang menyatakan bahwa pasien infark miokard akut/ IMA lebih sering terjadi secara signifikan dibandingkan dengan pasien stroke pada usia lebih muda dari 65 tahun $(51 \%$; $n=106$, pada kelompok pasien IMA dan $26 \%$; $n=380$, pada pasien stroke; $p: 0,042)$ Demikian juga pernyataan Lemone dan Burke (2008) mengatakan bahwa usia merupakan salah satu faktor yang tidak bisa diubah dan terdapat lebih dari $50 \%$ serangan jantung pada usia 65 tahun. Hasil uji statistik membuktikan tidak ada hubungan signifikan antara rerata umur dengan terjadinya VE ( $\mathrm{p}: 0,268$ $\alpha 0,05)$. Hasil penelitian ini juga sejalan dengan penelitian cross sectional dari Rahayu, Nurrachmah, dan Gayatri (2008) yang meneliti tentang faktor-faktor yang berhubungan dengan kolesterol total, TDD, peminum miras. Ad hubungan bermakna antara kolesterol dengan VE pada pasien IM ( $\mathrm{p}$ value 0 , analisis regresi logistik adalah $\mathrm{OR}=5,96\left(95^{\circ}\right)$ 1,73-20,52) artinya pasien IM dengan koles total berpeluang 7 kali mengalami VE dari kolesterol total tidak berisiko setelah diko TDD, kepribadian tipe-D dan peminum min keras. Ada hubungan yang bermakna a TDD dengan VE pada pasien IM ( $\mathrm{p}$ value 0 , dan uji regresi logistiK OR=5,78 (95\%CI: $20,29)$. Berarti pasien IM dengan TDD ber berpeluang 6 kali mendapat VE dibanding tidak berisiko setalh dikontrol tipe-D, koles total dan peminum miras.

Hasil analisis multivariate didapatkan var yang paling berhubungan dengan $\mathrm{VE}$ ac variable kepribadian tipe-D dengan nilai OR Berdasarkan pemodelan tahap akhir s aplikasi untuk melihat prediksi be probabilitas kepribadian tipe-D, kolesterol berisiko, dan TDD berisiko. Hasil ters menunjukan kemungkinarı VE sebesar $99 \%$ pasien infark miokard.

VE pada pasien penyakit jantung koroner di RSU Cibabat Cimahi dan RS Raja Bandung pada subjek PJK sebesar 40 or Hasil menunjukan bahwa umur t berhubungan signifikan dengan VE $(p: 0,70$ 0,05).

Persamaan dengan penelitian tersebut ad menggunakan rancangan cross sectional, dan ukur VE Maastricht Questionnaire 21 pertanyaan, juga beberapa karakteristik su PJK yang diteliti berhubungan dengan VE sep umur, jenis kelamin, dan status perkawinan. Perbedaan dengan penelitian ini adalah s penelitian dimana pada penelitian ini s. adalah pasien IM dengan rentang usia antar 65 tahun sementara pada penelitian oleh $\mathrm{Rah}$ Nurachmah, dan Gayatri (2008) subjeknya pasien PJK, yang kemungkinan besar ada pa IM dengan besar sampel berbeda $\left(\mathrm{N}=40^{\circ}\right.$ rentang umur responden lebih tua yaitu dí 40-85 tahun.

Proporsi jenis kelamin pada subjek penelifien lebih banyak pada laki-laki yaitu 88,286 
mpuan $11,8 \%$. Hal ini seperti yang atakan oleh Djohan (2004), bahwa gejala sebelum usia 60 tahun didapatkan satu dari laki-laki dan satu dari tujuh perempuan. Ini rti laki-laki mempunyai risiko PJK 2-3 tiga lebih besar dari perempuan. Sedangkan orsi jenis kelamin yang mengalami VE lebih r pada perempuan yaitu $87,5 \%$ dan laki-laki a $56,7 \%$. Namun hasil uji statistik unjukan tidak ada hubungan signifikan ra jenis kelamin dengan terjadinya VE $127, \alpha 0,05)$. Hasil penelitian ini mendukung litian Rahayu, Nurachmah dan Gayatri 8), dimana lebih besar subjek perempuan galami exhausted $78,8 \%$. Namun hasil uji aknaan menyatakan tidak ada hubungan ra jenis kelamin pada subjek PJK dengan dian VE ( $\mathrm{p}: 0,299)$.

$\mathrm{k}$ adanya hubungan bermakna antara jenis min dengan VE antara lain karena jumlah orsi subjek yang tidak berimbang antar laki$(88,2 \%)$ dan perempuan $(11,8 \%)$ yang inan subjek pada laki-laki sedangkan yang galami exhausted dominan pada perempuan. rnya subjek perempuan dengan IM yang galani exhausted pada penelitian ini dukung pernyataan Koertge (2003), bahwa penelitiannya membuktikan VE meningkat sering pada jerempuan. Demikian juga apat Popelka (2005) menyatakan dalam edaan gender pada manifestasi angina mpuan cenderung mengalami fatigue, udian diikuti nyeri, dan kelemahan. ngkan pada laki-laki yang pertama adalah kemudian diikuti fatigue dan kelemahan. an oleh Kop (1995) menyatakan fatigue VE memperlihatkan adanya prediksi awal lahului kejadian kekambuhan PJK.

orsi responden dengan riwayat keluarga if dalam penelitian ini adalah sepertiga dari sampel (35,3\%), sedangkan yang zalami VE pada lebih besar yaitu $70,8 \%$. un hasil uji statistik membuktikan riwayat rga tidak berhubungan signifikan dengan $\mathrm{p}: 0,293 ; \alpha 0,05)$.

eda halnya dengan hasil pada subjek lakisebagaimana yang diungkapkan oleh ott, et al (2003) pada penelitian yang sama, atakan bahwa riwayat keluarga berhubungan bermakna dengan VE $(\mathrm{N}=3961$ lakilaki; $\mathrm{p}: 0,001)$.

Hasil penelitian tersebut berbeda dengan penelitian ini, meskipun kurangnya besar sampel namun subjek lebih spesifik namun hasilnya kurang kuat untuk digeneralisasikan. Sementara penelitian tersebut mempunyai pengaruh yang kuat untuk digeneralisasikan karena mempunyai proporsi sampel yang besar dan dengan penelusuran keadaan subjek dengan pengukuran vital exhaustion dan fatigue. Sehingga hasilnya dapat membuktikan dan memprediksi keadaan pasien sekarang maupun keadaan status kesehatannya kedepan. Levine (2005) mengatakan bahwa keterkaitan riwayat keluarga, status kesehatan dan usia merupakan derajat utama anggota keluarga dalam menetapkan diagnosa apakah dalam keadaan hidup dan sehat, penurunan kesehatan sampai pada kematian. Riwayat IM pada keluarga inti mempunyai risiko duakali lipat dan apabila mempunyai anggota keluarga dekat yang mengalami penyakit yang sama akan berisiko IM tiga kali lipat (Newton \& Froelicher, 2005).

Pada penelitian ini sebagian besar subjek mempunyai pendamping atau sudah kawin (94\%). Pada dasarnya manusia adalah makluk sosial, sehingga interaksi dengan sesama sepanjang perjalan hidup sangat diperlukan. Dukungan sosial antara lain berasal dari hubungan perkawinan. Hubungan perkawinan saling menyenangkan dapat menurunkan kematian (Madān \& Froelicher, 2005). Pasien yang hidup sendiri mengalami $50 \%$ peningkatan risiko terjadinya serangan berulang. Pada pasien PJK dan IM yang tidak mempunyai dukungan emosional mempunyai risiko dua kali lipat untuk terjadinya serangan IM dan PJK atau keduanya (Madan \& Froelicher, 2005). Status cerai atau pisah dalam waktu lama diperkirakan sebagai faktor risiko independen terjadinya IM. Jika wanita yang mengalami distres pernikahan mempunyai risiko tiga kali lebih tinggi untuk terjadinya PJK berulang (Ortho-Gomer, et al 2000 dalam Madan \& Froelicher, 2005).

Proporsi responden yang mengalami VE lebih besar yang tidak ada pendamping (75\%) dibanding yang ada pendamping (59,4\%). Namun hasil uji statistik menunjukan tidak ada hubungan antara status keluarga dengan VE 
(p:0,543). Hasil ini sependapat dengan penelitian dari Rahayu, Nurachmah, Gayatri (2008) yang menyatakan tidak ada hubungan signifikan antara status keluarga dengan terjadinya VE.

Tidak ada hubungan yang bermakna pada kedua penelitian ini menurut peneliti karena keberadaan sampel yang kurang dan tidak berimbangnya partisipan yang tidak ada pendamping pada penelitian ini yaitu hanya $11,8 \%$ dan yang mengalami exhausted lebih tinggi $75 \%$. Demikian juga pada penelitian Rahayu, Nurachmah, Gayatri (2008) sampel yang tidak ada pendamping ada sebanyak $37,9 \%$ dan yang mengalami exhausted $81,8 \%$.

Hasil penelitian menunjukkan proporsi subjek yang mempunyai kebiasaan olahraga lebih tinggi $(64,7 \%)$, namun proporsi yang mengalami exhausted lebih banyak pada yang tidak biasa berolahraga yaitu $70,8 \%$. Hasil uji membuktikan $p=0,293$. Hal ini berarti tidak ada hubungan antara kebiasaan olahraga dan tidak berolahraga dengan kejadian VE.

Hasil yang sama telah dikemukakan oleh Bages, Appels dan Falger (1999) dalam case-contro study di Venezuela dengan subjek 74 orang ( 32 orang kasus MI dan kontrol 42 orang sehat) yang bertujuan untuk mengeksplorasi kekuatan diskriminasi dari VE antara kelompok kasus MI dan kontrol dengan menggunakan VE interview. Menyatakan bahwa exercise/ olahraga tidak ada hubungan yang bermakna dengan terjadinya VE $(\mathrm{p}: 0,119)$ lebih lanjut dengan pengujian likehood estimasi maksimum nilai OR adalah 17,55 setelah dipengaruhi oleh olahraga.

Persanaan hasil menurut peneliti pada kedua penelitian ini kemungkinan karena kurangnya jumlah sampel. Pada penelitian ini hanya 68 orang sedangkan pada penelitian Bages (1999), berjumlah 74 sampel. Dari pengujian dibuktikan estimasi maksimum nilai $\mathrm{OR}$ adalah 17,55 . Hal ini memperlihatkan penafsiran risiko terlalu tinggi karena kecilnya besar sampel dalam penelitian ini.

Olahraga dapat mengontrol faktor risiko penyakit kardiovaskuler. Menurut Ludington dan Diehl (2002), olahraga dapat menurunkan kolesterol LDL dalam darah dan meningkatkan kolesterol HDL, dapat menyingkirkan depresi, meredakan kegelisahan dan stres. Newton dan Froelicher (2005) merekomendasikan bahwa olahraga sedang selama 30 menit perhari dianjurkan un anak-anak dan orang dewasa.

Hasil analisis univariat menunjukkan bah responden peminum minuman keras hanya 16 namun sebagian besar dari respon terse mengalami exhausted $(90,9 \%)$ dan hasil anal bivariat menunjukan ada hubungan signifi. antara peminum minuman keras den terjadinya VE (p:0,049). Dari analisa diperc OR 8,387 (CI: 1,86-79,40) artinya respon dengan peminum minuman keras beris mempunyai peluang 8,3 kali mengal exhausted dibandingkan dengan responden ti berisiko.

Penelitian ini selaras dengan hasil penelitian Prescott, et al (2003) yang bertuj mendapatkan gambaran prevalensi gejala komunitas dan menentukan apakah ser prospektif memprediksi peningkatan ri penyakit jantung iskemik. Penelitian ters membuktikan bahwa peminum alk berhubungan bermakna dengan $\mathrm{VE}(\mathrm{N}=3$ laki-laki; tidak mengkonsumsi p:0,013; pemit alkohol lebih dari tiga gelas perhari p:0,0 demikian juga untuk kelompok perempuan tidak peminum (p:0,001) maupun pemi alkohol lebih dari tiga gelas perhari berhubur dengan VE $(N=5479 ; p: 0,001 ; \&$ p: 0,003$)$. Persamaan hasil dalam penelitian ini men peneliti karena mungkin terkait de: karakteristik gaya hidup lainnya termasuk makan buruk, kebiasaan kurang aktif dan psikologi. Karena terbukti stres psikologi kebiasaan gaya hidup yang buruk member kontribusi secara independen untuk res insulin yang menyebabkan penur kemampuan insulin untuk menekan asam le bebas. Hal ini mempertegas pernya Raikkonen, et al. (1996 dalam Koertge, 2 yang mengatakan kejadian VE berhubu dengan tiga atau empat hal yang dihadapi syndrome resisten insulin: kegem. hypergkikemia, dan dyslipidemia.

Proporsi responden perokok pada peneliti adalah lebih besar yaitu $70,5 \%$ dan mengalami exhausted sebesar $64,6 \%$. hasil uji menunjukan perokok tidak berhub secara signifikan dengan terjadinya VE pasien IM $(p=0,396 ; \alpha 0,05)$. Hasil penelis sejalan dengan pendapatnya Koetge, 
Schenck-Gustafsson, Orth-Gomer, dan Wamala (2003) pada penelitian tentang VE terkait dengan gaya hidup dan profil lipid pada wanita sehat ( $n=300$, rerata usia $56 \pm 7$ tahun) yang bertujuan menginvestigasi hubungan antara VE, gaya hidup dan profil lipid. Hasil temuan mereka membuktikan bahwa gaya hidup: merokok tidak berhubungan secara bermakna dengan VE (tidak merokok/ berhenti 1 tahun yang lalu; $\mathrm{p}=0,06$; perokok $>20$ batang/hari $p=0,81$ ).

Hasil penelitian ini meskipun menunjukan tidak ada hubungan secara bermakna, namun pengaruh merokok berdampak luas terutama pada kesehatan seseorang. Nikotin dan karbon monoksida dalam tembakau adalah penyebab utama yang menimbulkan penyakit pembuluh darah. Nikotin selain memberikan perasaan lembut santai, rasa senang, juga sebagai bahan yang membuat ketagihan. Nikotin juga mempersempit pembuluh darah kecil, membuat organ jantung, otak, paru-paru dan jaringan lainnya kekurangan oksigen yang vital. Selain nikotin, karbon monoksida secara langsung mengganggu kemampuan sel darah merah membawa oksigen. Hal ini menyebabkan, pernafasan pendek, kurang ketahanan, serta mendorong dan meningkatkan penyempitan serta pengerasan pembuluh arteri sehingga menjadi faktor risiko utama pada PJK. Risiko meningkat pada perokok lebih pada lamanya menjadi perokok, dan dimulai pada usia muda.

Menurut Newton \& Froelicher (2005), risiko terjadinya IM dua kali lipat pada perokok dibanding bukan perokok. Risiko relatif adalah 1,3 atau peningkatan risiko $30 \%$. Faktor risiko lainnya, seperti hipertensi, kadar kolesterol meningkat, kencing manis, dan lain-lain, bekerja secara sinergis terhadap terjadinya PJK.

Analisis univariat menunjukan $82,6 \%$ responden IM yang berkepribadian tipe mengalami VE. Hasil analisis juga mendapatkan nilai $\mathrm{p}=0,010$ yang berarti ada perbedaan bermakna antara kepribadian tipe-D dan bukan kepribadian tipeD dengan kejadian VE. Analisis lebih lanjut dengan multivariate didapatkan nilai odds ratio 6,8 hal ini berarti kepribadian tipe-D berpeluang 6,8 lipat mengalami VE dibanding dengan subjek bukan kepribadian tipe-D.

Penelitian ini menunjang penelitian Pedersen dan Middel (2001 dalam Williams, 2007) pada 171 pasien jantung iskemik yang menyatakan bahwa tipe-D meningkatkan risiko terjadinya VE enam kali lipat pada data awal dan lebih dari empat kali lipat merasakan fatigue setelah enam bulan kemudian diikuti dengan pengobatan.

Hasil penelitian ini juga mendukung hasil temuan oleh Pedersen, et al. (2007) yang bertujuan mengkaji prevalensi exhaustion, pengaruh kepribadian tipe-D pada exhaustion sepanjang waktu, dan kemaknaan klinik dari kepribadian tipe-D dibandingkan dengan jenis kelamin dan usia sebagai prediktor exhaustion pada 419 pasien percutaneous coronary intervention pada data dasar dan setelah setahun. Menyatakan bahwa kepribadian tipe-D secara bermakna mengalami peningkatan exhausted daripada pasien yang bukan kepribadian tipe-D $(p<0,001)$, dan mengalami peningkatan gejala exhausted secara umum $(\mathrm{p}=0,03)$. Lebih lanjut dikatakan tipe-D tetap sebagai prediksi independen pada exhausted selama setahun, setelah dokontrol oleh demografi dan faktor-faktor risiko klinis.

Penelitian ini telah ditunjang dari beberapa temuan yang menunjukan bahwa individu yang mempunyai kepribadian tipe-D mempunyai pengaruh terjadinya VE. Pada penelitian ini kepribadian tipe-D merupakan faktor paling dominan pada variabel dependen lain seperti kolesterol total dan tekanan darah diastolik. Hal ini karena kepribadian tipe-D yang mempunyai dua ciri kepribadian yaitu afek negatif (AN) dan hambatan sosial (HS) yang saling berinteraksi. Tingginya AN dan HS menurut Denollet, Vaes dan Brutsaert (2000), yang meneliti pada 800 pasien jantung menunjukan adanya interaksi pada kedua ciri kepribadian tersebut. Lebih lanjut dikatakan mempunyai hubungan dengan terjadinya PJK, khususnya terkait dengan keadaan depresi dan dukungan sosial yang rendah, marah cemas, permusuhan dengan VE.

Berdasarkan hasil analisis proporsi pada subjek dengan IMT berisiko dan tidak berisiko yang mengalami exhausted hampir berimbang $(60,7 \%$ \& $60 \%$ ). Ignatavicius (2006) mengatakan bahwa IMT 25-29,9 merupakan indikasi BB berlebihan, IMT $\geq 30$ indikasi obesitas dan peningkatan risiko masalah kesehatan, dan IMT $>40$ Morbid obesitas memberikan pengaruh negatif terhadap kesehatan. Selanjutnya oleh Hagan dan Ignatavicius (2006) menyatakan obesitas terkait 
dengan stres mental dan penyakit jantung, yang juga berhubungan dengan peningkatan kolesterol, tekanan darah dan toleransi glukosa. Keterkaitan keadaan stres mental, kecemasan, putus asa, mendorong individu dalam ketidak mampuan mengontrol kesehatannnya. Sehingga beberapa peneliti menyatakan exhaustion dan obesitas merupakan mata rantai yang tidak bisa diputuskan. Namun hasil uji lebih lanjut didapatkan hubungan tersebut tidak bermakna.

Penelitian ini mendukung temuan dari Koertge (2003) yang meneliti tentang VE dan PJK pada perempuan sehat $(n=299$, rerata umur $55,3 \pm 7,63$, rentang 30-65 tahun), dengan analisa uji chisquare $\mathrm{p}=0,41$, berarti IMT berdasarkan kuartil tidak berhubungan dengan VE

Proporsi subjek dengan kolesterol berisiko lebih tinggi mengalami exhausted $(76,3 \%)$ dibanding dengan subjek dengan kolesterol total tidak berisiko ( $40 \%)$ yang mengalami exhausted. Hasil analisis lebih lanjut ditemukan $p=0,003$ hal ini berarti kolesterol total berhubungan dengan VE. OR 5,96 (CI:1,73-20,52) berarti pasein IM dengan kolesterol $>200 \mathrm{mg} / \mathrm{dl}$ mempunyai peluang 5,96 kali terjadinya VE. Pada penelitian jantung di Framingham, oleh Bush (1988, dalam Newton \& Froelicher, 2005) menyatakan konsentrasi kolesterol serum $>295 \mathrm{mg} / \mathrm{dl}$ mempunyai lebih dari tiga kali berisiko terjadinya IM dengan konsentrasi kolestero $<204 \mathrm{mg} / \mathrm{dl}$.

Temuan ini mendukung hasil penelitian oleh van Doornen dan van Bloklan (1986, dalam Koerge, 2003) tentang hubungan antara kolesterol derigan VE ( $N=33$; subjek laki-laki dewasa sehat) menyatakan hubungan posistif sebelum, selama dan sesudah stres akut. Menurut Smith, et al (2009) peningkatan metabolisme lipid berhubungan dengan VE. Secara patofisiologis VE dapat mempengaruhi penyakit kardiovaskuler melalui metabolism lipid (Rainkkonen, 1997), metabolism lipid (hypeinulinemia, dislipidemian dan penimbunan lemak diperut) hal ini akan merangsang peningkatan pengeluaran hormon andrenocortiotropic (ACTH) yang menyebabkan perubahan perbandingan -hydorxyprogesterone (17-OHP) ke 11-deoxycortiso I sehingga menyebabkan vital exhaustion (Raikkonen, 1997).

Hasil penelitian ini berbeda dengan hasil penelitian yang dilakukan oleh Koertge, et al
(2003) tentang VE dalam hubungannya der gaya hidup dan profil lipid pada wanita s $(\mathrm{N}=300)$ pada rentang usia $31-65$ tahun. I penelitian ini menunjukan bahwa tidak hubungan antara kolesterol total dengan (p:0,62).

Hasil penelitian yang berbeda dengan penel ini juga dikemukakan oleh Koertge (2003) penelitian tentang pengaruh VE kekambuhan PJK sampel pada wanita mempunyai risiko IMA selama periode tahun ( $\mathrm{n}=110$; rentang usia $30-65$ ta menyatakan kolesterol total tidak berhubus dengan VE ( $p: 0,60)$. Secara klinis didapa hasil yang berhubungan tetapi hasil an membuktikan tidak ada hubungan as kolesterol total dengan VE.

Perbedaan hasil ini dengan temuan Keoertge, (2003) dan Koertge (2003) menurut per karena kolesterol serum mudah dikendal dengan diet dan pengobatan. Penelitian ini subjek yang sementara dirawat di rumah sehingga intervensi pengobatan tidak dielakkan sementara pengobatan tidak ekspl terkait dengan kolesterol sebelum ma sementara pasien dirawat. Demikian juga penelitian tersebut tidak dijelaskan te dengan pengobatan maupun diet/ kebia makan responden. Perbedaan yang lain yaitu rancangan penelitian dimana pada penelitia menggunakan cross sectional design sedan pada penelitian Koertge, et al (2003) dan Koe (2003) menggunakan prospective design.

Proporsi responden dengan HDL berisiko sedikit $(33,82)$ dibanding yang tidak ber $(66,17 \%)$, dan lebih mengalami exhausted kelompok HDL tidak berisiko $62,2 \%$, sedan kelompok HDL bersiko yang menga exhausted $56,5 \%$. Hasil analisis membuk tidak ada hubungan signifikan antara dengan terjadinya VE pada pasien $\mathrm{IM}(\mathrm{p}=0,6$ 0,05 ).

Hasil ini menunjukan bahwa tidak ada peng antara responden dengan HDL kolesterol $\mathrm{mg} / \mathrm{dl}$ (berisiko) dengan responden mempunyai $\mathrm{HDL}$ normal $35-55 \mathrm{mg} / \mathrm{dl}$ berisiko). Temuan ini kemungkinan disebabkan dengan hampir berimbangnya a kelompok berisiko dan tidak berisiko o mengalami exhausted. 
Peningkatan lemak dalam darah dan lipoprotein memicu atherosclerosis karena LDL menimbun kolesterol ke dinding arteri, sedangkan HDL membantu membersihkan kolesterol pada dinding arteri. Tingginya kadar LDL dalam darah lebih dari $130 \mathrm{mg} / \mathrm{dl}$ merupakan risiko terjadinya PJK (LeMone \& Burke, 2008).

Penelitian ini menunjukan proporsi responden dengan LDL berisiko lebih rendah yaitu $26,4 \%$. Sedangkan yang mengalami exhausted lebih besar $(66,7 \%)$. Namun hasil uji statistik menunjukan tidak ada hubungan LDL dengan kejadian VE (p:0,520; $\alpha 0,05)$.

Pada penelitian ini proporsi terbesar responden dengan $\mathrm{TDD} \geq 80 \mathrm{mmHg}$ adalah $61,7 \%$ sedangkan yang mengalami exhausted sebesar $73,8 \%$. Berdasarkan hasil uji statistik membuktikan ada hubungan yang signifikan antara TDD dengan terjadinya VE (p:0,005; $\alpha$ 0,05 ). Dimana TDD $\geq 80 \mathrm{mmHg} /$ berisiko berpeluang mengalami exhausted 5,7 kali dibandingkan dengan TDD $<80 \mathrm{mmHg} /$ tidak berisiko.

Menurut LeMone dan Burke (2008), tekanan darah tinggi atau hipertensi dapat berpengaruh pada kerusakan sel endothelial arteri, yang menyebabkan peningkatan tekanan dan terjadi perubahan karakteristik aliran darah yang menstimulasi plak atherosklerosis, hipertensi berisiko tiga sampai empat kali lipat terjadinya PJK dan IM. Selanjutnya oleh Blach (2006)

\section{KESIMPULAN}

Rerata umur 53,81 tahun dengan jenis kelamin terbanyak pada laki-laki $88,2 \%$, kebanyakan subjek mempunyai pasangan $94,1 \%$, ada riwayat keluarga dengan penyakit yang sama $35,3 \%$, perokok $30,9 \%$, hanya $16,2 \%$ mempunyai kebiasaan konsumsi minuman keras dan tidak biasa berolahraga sebesar $67,6 \%$.

Kebiasaan konsumsi minuman keras berhubungan signifikan dengan vital exhaustion sementara karakteristik: umur, jenis kelamin, riwayat keluarga, status keluarga, olahraga, dan perokok tidak berhubungan dengan Vital exhaustion pada pasien IM di RSUPN Cipto Mangunkusumo dan RSJPD Harapan Kita Jakarta. Kepribadian tipe-D dan faktor fisologi: kolesterol total dan tekanan darah diastolik/ TDD berhubungan signifikan dengan Vital mengatakan hipertensi juga dapat menurunkan curah jantung sehingga suplai darah keseluruh tubuh berkurang yang mengakibatkan rendahnya stroke volume dan metabolisme anaerobik pada otot skeletal hal ini yang menyebabkan fatigue.

Berbeda halnya dengan penelitian dari Jeanmonod, et al (2004) yang meneliti pengaruh VE berat pada tingkat plasma C-reactive protein (CRP) dan apakah exhaustion berpengaruh pada regulasi tingkat CRP pada pekerja pembuatan pesawat terbang di Jerman selatan $(\mathrm{N}=275)$ dimana dari TTD tidak ada hubungan dengan tingkat exhausted: rendah, menengah dan tinggi (p:0,85; $\alpha 0,05)$. Meskipun sasarannya sama untuk membuktikan hubungan faktor risiko penyebab VE.

Perbedaan pada hasil penelitian ini menurut peneliti kemungkinan besar karena beda subjek penelitian. Pada penelitian Jeanmonod, et al. (2004) subjek penelitian pada karyawan industri pesawat sedangkan pada penelitian ini pada pasien IM. kelemahan pada penelitian ini subjek sudah dirawat sehingga kemungkinan besar pengobatan berpengaruh pada penurunan atau peningkatan TDD subjek dan atau terkontrol, sedangkan pada subjek penelitian dari Jeanmonod, et al. (2004) tidak ada informasi tentang subjek menggunakan pengobatan terkait dengan TDD, atau kemungkinan tidak terpengaruh oleh pengobatan.

exhaustion, sedangkan indeks masa tubuh/ IMT, higt density lipoprotein/ HDL dan low density lipoprotein/ LDL tidak berhubungan signifikan dengan Vital exhaustion pada pasien IM di RSUPN Cipto Mangunkusumo dan RSJPD Harapan Kita Jakarta. Pasien IM yang berkepribadian tipe-D mempunyai peluang 6,8 kali mengalami VE dibanding bukan tipe-D setelah dikontrol kolesterol total, TDD dan konsumsi minuman keras. Pasien IM dengan kolesterol total $>200 \mathrm{mg} / \mathrm{dl}$ mempunyai peluang lima kali mengalami VE dibanding dengan pasien IM dengan kolesterol total $\leq 200 \mathrm{mg} / \mathrm{dl}$ setelah dikontrol kepribadian tipe-D, TDD, dan konsumsi minuman keras. Pasien IM dengan TDD $\geq 80$ mmHg mempunyai peluang 5,3 kali mengalami VE dibanding pasien IM dengan TDD 
$<80 \mathrm{mmHg}$ setelah dikontrol kepribadian tipe-D, kolesterol total dan konsumsi minuman keras. Faktor yang paling berhubungan dengan VE pada pasien IM di RSUPN Cipto Mangunkusumo dan RSJPD Harapan Kita Jakarta adalah Kepribadian tipe-D.

Penelitian ini merekomendasikan perlunya menyempurnakan format pengkajian meliputi pengkajian mental psikososial antara lain vital exhaustion dan kepribadian tipe-D, dan faktor fisiologi serta gaya hidup yang menjadi bagian dalam mengeksplorasi pelaksanaan dan evaluasi asuhan keperawatan pada pasien penyakit arteri koroner termasuk infark miokard akut.

Perlu adanya program pelatihan bagi perawat tentang pengkajian faktor risiko metal psikososial, faktor fisiologis, dan gaya hidup yang dapat menyababkan IM yang berkesinambungan sesuai dengan jenjang karir perawat disetiap tatanan pelayanan kesehatan,

\section{KEPUSTAKAAN}

Bages, N., Appels, A., \& Falger, P.R.J. (1999). Vital exhaustion as a risk factor of myocardial infarction: a case-control study in Venezuela. International Journal of Behavioral Medicine, 6(3), 279-290.

Bryant, M.J.. Stevens, J.. Truesdale, K.P.. Mosley, T.. \& Chambless, L. (2008). Obesity and vital exhaustion: analysis of the Atherosclerosis Risk in the Communities study. Obesity a research journal (2008) 16 (7), 1545-1551.

Denollet, J., \& Brutsaert, D.L (1998). Personality, Disease Severity, and the Risk of Long-term Cardiac Events in Patients With a Decreased Ejection Fraction After Myocardial Infarction. Circulation 1998;97;167-173 American Heart Association Inc.

Denolet, J., Vaes, J., \& Brusaert, D.L. (2000). Inadequate response to treatment in coronary heart disease: Adverse effects of type-D personality and younger age on 5-prognosis and quality of life. Circulation: journal of the American Heart Association, 2000; 102;630-635.

El-Mokadem, N. (2003) The relationship between fatigue, depression, and sleep disturbance after MI. Ann Arbon: ProQuest Information and Learning company. dan mengembangkan program peningk pendidikaan pengembangan sumber manusia perawat sehingga memiliki kompet dalam pengkajian dan penelitian.

Sebagai dasar untuk melakukan penel lanjutan tentang intervensi terapi modalitas pasien berkepribadian tipe-D (pada kedua afek negatif dan hambatan sosial) terhadap exhaustion dengan rancangan yang berbeda dengan sampel yang lebih besar, dapat der variasi penyakit jantung dan atau dipenga antara lain oleh latar belakang budaya, hidup, dan kualitas hidup. Perlunya dilakı penelitin complementary and altern medicinel CAM seperti intervensi Mind-l (termasuk meditasi, musik terapi, dan cogni behavioral therapy), terapi energi (reiki, te sentuhan) untuk vital exhaustion dengan de quasi.

Gallacher, E.J., Sweetnam, P.M., Yarnell, N \& Elwood, P.C. (2003). Is type A beha really a trigger for coronary heart ev Psychosomatic medicine. 65:339American Psychosomatic Society.

Gray, H.H., Dawkins, Morgan, \& Simp (2002) Lecture notes: Kardiologi, bahasa oleh Azwar Agoes dan Rachmawati, 2005, Surabaya: Pen Airlangga.

Inatavicius, D.D. (2006). Interventions for $\mathrm{cl}$ with malnutrition and obesity, d Inatavicius, D.D. \& Workman, M.L.(I Medical surgical nursing: critical thin for caollaborative care. (hlm. 839-\{ St.Louis: Elsevier Saunders.

Ivanusa, M., \& Ivanusa, Z. (2004). Risk fa and in-hospital outcomes in stroke myocardial infarction patients. Mio Central Public Health. 2004;4:26

Jenamonod, P., von Kanel, R., Maly, F.E Fischer, J.E. (2004). Elevated plasm: reactive protein in chronically distre subjects who Carry the a allele of the TI -308G/A polymorphism. Psychoson Medicine 66:501-506 (2004) 3174/04/6604-0501. 
Kilbourn, K., Saab, P., \& Schneiderman, N. (2000). Depression and negative affect in post-myocardial infaction patient: assessment and treatment implication dalam Johnson, S.L., Yahes, A.M., Field, T.M., Schneiderman, N.,\& McCabe, P.M (Eds). Stress, coping, and depression. (hlm 265270).Lawrence Erlbaum Associates.

Koertge, J. (2003). Vital exhaustion and coronary artery disease in women: Biological correlates and behavioral intervention. Thesis. Sweden, Stocholm: Karolinska University Press.ISBN

Koertge, J.C., Ahnve, S., Schenck-Gustafsson, K., Orth-Gomer, K.,\& Wamala, S.P. (2003). Vital exhaustion in relation to lifestyle and lipid profile in healthy women. Int J Behav Med. 10 (1):44-45.

Kop, W. J., Appels, A.P.W.M., Mendes, C.F., Swart, H.B., \& Bar, F.W. (1994). Vital exhaustion predicts new cardiac after successful coronaryangioplasty, dalam Psychosomatic medicine 56: 282-287 hlm. The American psycomatic society.

Lemone, P., \& Burke, K.M. (2008). Medical surgical nuring: critical thinking in client care. Philadelphia, New Jersy: Pearson education inc.

Levine, B.S., (2005). History taking and physical examination dalam Woods, S.L, Froelicher, E.S., Mtzer, S.A.,\& Bridges, E.J.(Eds), Cardiac nursing (5 $5^{\text {th }}$ ed.), (hlm 229-295). Philadelphia: Lippincott William \& Wilkins.

Ludington, A., \& Diehl, H. (2002). Dynamic living. Loma Linda, California. Lifestyle Medicine Institute.

Madan, S.K., \& Froelicher, E.S. (2005). Psychosocial risk factors: assessment and management dalam Woods, S.L, Erika S.R, Motzer, S.A., and Bridges, E.J.(Eds) Cardiac nursing ( $5^{\text {th }}$ ed). (Hlm.809824).Philadelphia: Lippincott Williams \& Wilkins.

Newton, K.M., \& Froelicher, E.S. (2005). Coronary heart disease risk factors dalam Woods, S.L, Erika S.R, Motzer, S.A., \& Bridges, E.J. Cardiac nursing $\quad\left(5^{\text {th }}\right.$ ed. $)$, (HIm.809-824). Philadelphia: Lippincott Williams \& Wilkins.
Pedersen, S.S., Lemon, P.A., van Vooren, P.R., Liu, T.K., Daemen, J., Erdman, R.A., Smits, P.C., Serruys, P.W.J.C., \& van Domburg, R.T., (2004). Type D personality predicts death or myocardial infarction after bare metal stent or sirolimus-eluting stent implantation: a Rapamycin-Eluting Stent Evaluated at Rotterdam Cardiology Hospital (RESEARCH) registry substudy. Journal of the Amrican Colegeofl Cardiology. 2004 Sep 1;44(5):997-1001.Elsevier Inc.

Pedersen, S.S., Daemen, J., van de Sande, M., Sonnenschein, K., , Serruys, P.W., Erdman, R.A.M., \& van Domburg, R.T. ( 2007). Type-D personality exerts a stable,adverse effect on vital exhaustion in PCI patients treated with paclitaxel-eluting stents Journal of Psychosomatic Research 62 (2007) 447453

Popelka, K.,A. (2005).Assessment of the cardiac system dalam Black, J.M dan Hawks, J.H. Medical surgical nursing: clinical management fro positive outcome. ( $7^{\text {th }}$ ed.) (hlm. 1560-1598). St. Louis, Missouri: Elsevier Saunders.

Prescott, E., Holst, C., Gronbaek, M., Schnohr, P., Jensen, G., \& Barefoot, J. (2003). Vital exhaustion as. A risk factor for ischaemic heart disease and all-cause mortality in a community sample. A prospective study of 4080 men and 5479 women in the Copenhagen City Heart Study, International Journal of Epidmiology , 990-997.

Rahayu, U., Nurachmah, E., \& Gayatri, D. (2008). Faktor-faktor yang berhubungan dengan vital exhaustion pada pasien penyakit jantung koroner (PJK) di RSU. Cibabat Cimahi dan RS Rajawali Bandung. Tesis (tidak dipublikasikan). Program Pasca Sarjana Fakultas Ilmu Keperawatan Universitas Indonesia.

Raikkonen, K. (1997). Vital exhaustion- $a$ syndrome of psychological distress, dalam John, D.,\& MacArthur, C.T. 